\title{
Transgenic Expression of Human Connexin32 in Myelinating Schwann Cells Prevents Demyelination in Connexin32- Null Mice
}

\author{
Steven S. Scherer, ${ }^{1}$ Yi-Tian Xu, ${ }^{1}$ Albee Messing, ${ }^{4}$ Klaus Willecke, ${ }^{3}$ Kenneth H. Fischbeck, ${ }^{1,5}$ and Linda Jo Bone Jeng ${ }^{2}$ \\ ${ }^{1}$ Department of Neurology and ${ }^{2}$ Cell and Molecular Biology Graduate Group, The University of Pennsylvania Medical Center, Philadelphia, Pennsylvania \\ 19104, ${ }^{3}$ Institut fuer Genetik der Universitat Bonn, Abteilung Molekulargenetik, D-53117 Bonn, Germany, ${ }^{4}$ Department of Pathobiological Sciences, School \\ of Veterinary Medicine, University of Wisconsin-Madison, Madison, Wisconsin 53706, and ${ }^{5}$ Neurogenetics Branch, National Institute of Neurological \\ Disorders and Stroke-National Institutes of Health, Bethesda, Maryland 20892-1250
}

\begin{abstract}
Mutations in Gap Junction $\boldsymbol{\beta} 1$ (GJB1), the gene encoding the gap junction protein connexin32 (Cx32), cause the X-linked form of Charcot-Marie-Tooth disease (CMT1X), an inherited demyelinating neuropathy. We investigated the possibility that the expression of mutant Cx32 in other cells besides myelinating Schwann cells contributes to the development of demyelination. Human Cx32 was expressed in transgenic mice using a rat myelin protein zero $(\mathrm{Mpz})$ promoter, which is exclusively expressed by myelinating Schwann cells. Male mice expressing the human transgene were crossed with female Gjb1/cx32-null mice; the resulting male offspring were all cx32-null (on the X chromosome), and one-half were transgene positive. In these transgenic mice, all of the Cx32 was derived from the expression of the transgene and was found in the sciatic nerve but not in the spinal cord or the liver. Furthermore, the Cx32 protein was properly localized (within incisures and paranodes) in myelinating Schwann cells. Finally, the expression of human Cx32 protein "rescued" the phenotype of $c x 32$-null mice, because the transgenic mice have significantly fewer demyelinated or remyelinated axons than their nontransgenic littermates. These results indicate that the loss of Schwann-cell-autonomous expression of Cx32 is sufficient to account for demyelination in CMT1X.
\end{abstract}

Key words: axon-Schwann cell interactions; Charcot-Marie-Tooth disease; CMT; myelin; Schwann cells; gap junctions; Cx32

\section{Introduction}

Myelin sheaths are a multilamellar spiral of specialized membrane formed by Schwann cells in the PNS and oligodendrocytes in the CNS (Scherer et al., 2004; Trapp and Kidd, 2004). By limiting axonal depolarization to nodes of Ranvier, the periodic interruptions between myelin internodes, myelin increases axonal conduction velocity. PNS and CNS myelin sheaths are structurally similar but chemically distinct. Both consist mostly of lipids, including cholesterol and glycolipids, but each contains a unique but overlapping set of proteins. In the PNS, myelin protein zero $\left(\mathrm{P}_{0}\right)$, peripheral myelin protein $22 \mathrm{kDa}$ (PMP22), and myelin basic protein $(\mathrm{MBP})$ are the main proteins in compact myelin;

Received July 28, 2004; revised Jan. 3, 2005; accepted Jan. 3, 2005

This work was supported by the Medical Scientist Training Program (L.J.B.J.) and by National Institutes of Health Grants R01 NS08075 (K.H.F. and S.S.S.) and R01 NS42878 (S.S.S.). We thank Drs. Scott Kasner, John Kern, and especially Rachel Weinstein for statistical advice; Marion Oronzi Scott and Drs. Suzanne Deschênes and Diane Merry for helpful discussions; Qian Chen, Melissa Davey, Sharon Seltzer, Erich Sirkowski, Denise Springman, and Suping Wang for technical assistance; Dr. Larry Wrabetz for the gift of the Mpz promoter and advice on PCR site-directed mutagenesis; and Drs. David Colman, Elliot Hertzberg, Virginia Lee, Sarah Piddleston, and James Salzer for antibodies.

Correspondence should be addressed to Dr. Steven S. Scherer, The University of Pennsylvania Medical Center, 464 Stemmler Hall, 36th Street and Hamilton Walk, Philadelphia, PA 19104-6077. E-mail: sscherer@mail.med.upenn.edu.

L. J. B. Jeng's present address: Departments of Pediatrics and Genetics and Center for Human Genetics, University Hospitals of Cleveland and Case Western Reserve University, Cleveland, $\mathrm{OH} 44106$.

D0I:10.1523/JNEUROSCI.3082-04.2005

Copyright $\odot 2005$ Society for Neuroscience $\quad$ 0270-6474/05/251550-10\$15.00/0 the main ones in the CNS are proteolipid protein and MBP. In addition to compact myelin, PNS myelin sheaths also have domains of noncompact myelin that contain myelin-associated glycoprotein (MAG) as well as the molecular components of adherens junctions, tight junctions, and gap junctions, including the gap junction protein connexin32 (Cx32). Although these junctions are classically described between apposed cells in various epithelia, they link apposed surfaces of the same cell in the PNS myelin sheath.

Inherited demyelinating neuropathies are a clinically and genetically heterogeneous group of diseases including the dominantly inherited, demyelinating forms of Charcot-Marie-Tooth disease (CMT1), as well as milder and more severe neuropathies (Dyck et al., 1993b; Lupski and Garcia, 2001; Wrabetz et al., 2004). Dominant mutations in PMP22, MPZ/P0, and GJB1/CX32 cause CMT1A, CMT1B, and CMT1X, respectively. How these mutations cause demyelination is unknown, but it is likely that myelinating Schwann cells are affected first. For example, $\mathrm{P}_{0}$ mRNA and protein appear to be exclusively expressed by myelinating Schwann cells in adult animals, so that the demyelination is probably Schwann cell autonomous (Kirschner et al., 2004). Myelinating Schwann cells also express Cx32 (Scherer et al., 1995), but Cx32 is also expressed by some neurons and many other cell types (Yamamoto et al., 1991; Micevych et al., 1996; Bennett et al., 1999; Solomon et al., 2001). Because it is possible 
that the expression of $\mathrm{Cx} 32$ by other cell types contributes to the development of the demyelinating neuropathy, we expressed the human GJB1/Cx32 gene in transgenic mice using the rat $M p z$ promoter, which is expressed exclusively by myelinating Schwann cells (Lemke et al., 1988; Messing et al., 1992). Male transgenic mice were crossed with female $c \times 32$-null mice; the resulting male offspring were all $c x 32$ null, and equal proportions were transgene positive $\left(\mathrm{TG}^{+}\right)$and negative $\left(\mathrm{TG}^{-}\right)$. Myelinating Schwann cells expressed this transgene, and the human Cx32 protein was properly localized (to paranodes and incisures) and prevented the development of demyelination in $c \times 32$-null mice. These findings provide strong evidence that the effects of GJB1/ Cx32 mutations are initially manifested in the myelinating Schwann cells themselves.

\section{Materials and Methods}

Generation of Cx32 mutant mice. The generation and initial characterization of $c \times 32$-null $\left(c \times 32^{-1-}\right.$ female and $\left.c \times 32^{-/ Y}\right)$ mice has been described (Nelles et al., 1996; Anzini et al., 1997; Scherer et al., 1998). Animals were generated from our colony at the University of Pennsylvania (Philadelphia, PA) by PCR analysis of genomic DNA isolated from tail clips (Anzini et al., 1997) and confirmed by Southern blot analysis (Abel et al., 1999).

The creation of mice expressing a GJB1 mutation (Arg175 frameshift) with a $1.1 \mathrm{kB}$ rat $M p z$ promoter fused to the human GJB1 gene has been described (Abel et al., 1999). A genomic clone of GJB1 was isolated from a human $\mathrm{X}$ chromosome genomic library using probes for exon 1a and exon 2 (see Fig. 1A). Based on the characterization of the P2 promoter, which is active in peripheral nerve (Neuhaus et al., 1995, 1996; Söhl et al., 1996), a $5.3 \mathrm{~kb}$ NdeI/SacI fragment containing exon 1b, exon 2, and a 355 bp intron was isolated. A $1.1 \mathrm{~kb}$ fragment containing the rat $\mathrm{Mpz}$ promoter (Lemke et al., 1988) was purified and cloned upstream of the NdeI/SacI GJB1 fragment in the appropriate orientation; this removed the TATAA box of the P2 promoter. This construct was designated $\mathrm{P} 0 \mathrm{Cx} 32 \mathrm{WT}$ and is shown in Figure $1 B$.

A $6.4 \mathrm{~kb}$ transgene cassette for each clone was released from vector sequences by digestion with ApaI and NsiI. The fragment was isolated, purified, and microinjected into the male pronucleus of fertilized eggs obtained from FVB/N mice (Taketo et al., 1991) (Taconic Farms, Germantown, NY), according to standard protocols (Brinster et al., 1985). Eggs that survived microinjection were then placed into pseudopregnant foster mice for gestation. Transgenic progeny were identified by PCR with transgene-specific primers $<\mathrm{P} 0>\left(5^{\prime}\right.$-CAG TTC CTT GTC CCC CGC TCT CTC- $3^{\prime}$ ), which recognizes the 24 bp immediately $3^{\prime}$ of the transcription start point, and $<2>\left(5^{\prime}\right.$-TTG CTG GTG AGC CAC GTG CAT GGC- $3^{\prime}$ ), a sequence within the open reading frame of $C \times 32$, using the following conditions: $94^{\circ} \mathrm{C} \times 5 \mathrm{~min}, 35$ cycles of $94^{\circ} \mathrm{C} \times 1 \mathrm{~min}$, $66^{\circ} \mathrm{C} \times 1 \mathrm{~min}, 72^{\circ} \mathrm{C} \times 1 \mathrm{~min}$, and then $72^{\circ} \mathrm{C} \times 10 \mathrm{~min}$. A $872 \mathrm{bp}$ product confirmed the presence of the transgene. In this way, we identified three transgenic lines and characterized two of them (hereafter called line 90 and line 96) that transmitted the transgene to their progeny.

Reverse transcription-PCR. Total RNA was isolated from snap-frozen sciatic nerves according to the RNAzol B (Tel-Test, Friendswood, TX) protocol for small amounts of tissue and quantitated by spectrophotometry. Reverse transcription (RT) was performed using $0.5-1 \mu \mathrm{g}$ of RNA, random primer $\mathrm{p}(\mathrm{dN})_{6}$ (Boehringer Mannheim, Indianapolis, IN), avian myeloblastosis virus (AMV) reverse transcriptase (Promega, Madison, WI), AMV RT $(5 \times)$ reaction buffer (Promega), RNase inhibitor (Boehringer Mannheim), and deoxynucleotide triphosphates (dNTPs; Ultrapure dNTP set; Pharmacia Biotech, Piscataway, NJ). Subsequent amplification of cDNA with primers (Fig. $1 B)<1>\left(5^{\prime}\right.$-TGA GGC AGG ATG AAC TGG ACA GGT- $\left.3^{\prime}\right)$ and $<4>\left(5^{\prime}\right.$-CAC GAA GCA GTC CAC TGT$\left.3^{\prime}\right)$ resulted in a $553 \mathrm{bp} \mathrm{PCR}$ product $\left(94^{\circ} \mathrm{C} \times 5 \mathrm{~min}, 40\right.$ cycles of $94^{\circ} \mathrm{C} \times$ $1 \mathrm{~min}, 60^{\circ} \mathrm{C} \times 1 \mathrm{~min}, 72^{\circ} \mathrm{C} \times 1 \mathrm{~min}$, and then $\left.72^{\circ} \mathrm{C} \times 10 \mathrm{~min}\right) . M s c \mathrm{I}$ cuts the human PCR product into two fragments ( 280 and $273 \mathrm{bp}$ ); HhaI cuts the mouse PCR product into two fragments ( 230 and $323 \mathrm{bp}$ ). Densitometry of the mouse- and human-specific bands within a single lane after digestion was used to estimate the relative levels of the transgene/human and endogenous/mouse mRNAs.

Immunoblot analysis. Protein was isolated from snap-frozen sciatic nerves and livers of adult mice, crushed in a mortar and pestle on dry ice, suspended in Tris-buffered SDS lysis buffer (50 mm Tris, pH 7.0, 1\% SDS, $0.017 \mathrm{mg} / \mathrm{ml}$ phenylmethyl sulfonyl fluoride) with or without $6 \mathrm{M}$ urea, and sonicated (Sonic Dismembrator; Fisher Scientific, Pittsburgh, PA). Samples were spun at $4^{\circ} \mathrm{C}$ to pellet insolubles, and the supernatant was measured by a protein assay (Bio-Rad, Hercules, CA). One hundred micrograms of protein per lane were loaded onto $12 \%$ SDS-PAGE gels and run at 10-20 $\mathrm{mA}$ overnight at room temperature with size markers (Rainbow markers; Amersham Life Sciences, Buckinghamshire, UK). Semidry transfer (Fisher Biotech, Pittsburgh, PA) to a nylon membrane (Immobilon-P transfer membrane; Millipore, Bedford, MA) was completed following the recommendations of Millipore and analyzed by Western blot analysis (Scherer et al., 1995). A hybridoma supernatant of the mouse monoclonal antibody 7C6.C7 (diluted 1:2) (Li et al., 1997) and a rabbit antiserum (diluted 1:1000; Zymed, San Francisco, CA) against Cx32 were diluted in 5\% milk in Tris-buffered saline. The primary antibodies were detected with peroxidase-coupled goat anti-mouse IgG1 heavy chain (1:2500 dilution; Southern Biotechnology Associates, Birmingham, $\mathrm{AL}$ ) or goat $\mathrm{F}\left(\mathrm{ab}^{\prime}\right)_{2}$ anti-rabbit IgG (1:2500 dilution; Jackson ImmunoResearch Laboratories, West Grove, PA). Membranes were developed by established enhanced chemiluminescence methods (Amersham Biosciences, Arlington Heights, IL) and exposed to autoradiography film (X-OMAT AR; Kodak Scientific Imaging, Rochester, NY). Some blots were reprobed with a rabbit antiserum against $\mathrm{P}_{0}$ (diluted 1:50,000) (D’Urso et al., 1990).

Immunohistochemistry. Because fixation in paraformaldehyde reduces Cx32 immunoreactivity (Scherer et al., 1995), we teased nerve fibers from unfixed nerves; these were dried on glass slides (SuperFrost Plus; Fisher Scientific), postfixed for $10 \mathrm{~min}$ with acetone, blocked at room temperature for at least $1 \mathrm{~h}$ in $5 \%$ fish skin gelatin containing $0.5 \%$ Triton $\mathrm{X}-100$ in PBS, and incubated for $24-48 \mathrm{~h}$ at $4^{\circ} \mathrm{C}$ with various combinations of primary antibodies. We used a mouse monoclonal antibody against rat $\mathrm{Cx} 32$ (7C6.C7; diluted 1:1), which recognizes an epitope in the C-terminal tail (Li et al., 1997) or a rabbit antiserum against rat Cx32 [usually from Chemicon (Temecula, CA), diluted 1:200, but also from Zymed, diluted 1:200; both against a peptide from the cytoplasmic loop]. The anti-Cx32 antibodies were usually combined with either a rat monoclonal antibody (DECMA; diluted 1:50; Sigma) or a rabbit antiserum (Fannon et al., 1995) (diluted 1:500) against E-cadherin or MAG (Pedraza et al., 1990) (diluted 1:500). A rat antibody against nonphosphorylated neurofilament-heavy (NF-H; Ta51, diluted 1:10) (Lee et al., 1982, 1987) was used to visualize axons. A mouse monoclonal antibody (Y11) (Piddlesden et al., 1991) against myelin-oligodendrocyte glycoprotein (MOG) was used to visualize oligodendrocyte myelin sheaths. After incubating with the primary antibodies, the sections were washed and incubated with the appropriate fluorescein-, rhodamine-, and cyanine-5conjugated donkey anti-rabbit, anti-mouse, and/or anti-rat secondary antibodies (Jackson ImmunoResearch Laboratories). These preparations were imaged with epifluorescence tetramethylrhodamine isothiocyanate and FITC optics on a Leica DMR light microscope equipped with a cooled Hamamatsu (Bridgewater, NJ) camera or with a Leica TCS laser scanning confocal microscope, followed by image manipulation with Adobe Systems (San Jose, CA) Photoshop. Where appropriate, the images were made with comparable exposure times to allow better comparison between mice of different genotypes.

Light and electron microscopy. For the transgenic line 90, we examined litters of $c \times 32^{-/ Y}$ mice at postnatal day 158 (P158) (two TG ${ }^{+}$), P250 (two $\mathrm{TG}^{-}$and two $\mathrm{TG}^{+}$), and P365 (two $\mathrm{TG}^{-}$and three $\mathrm{TG}^{+}$). Mice were deeply anesthetized with chloral hydrate and were then perfused with $0.9 \% \mathrm{NaCl}$ followed by $3 \%$ glutaraldehyde in $0.1 \mathrm{~m}$ phosphate buffer. The spinal cord and attached roots, as well as sciatic and femoral nerves, were removed and placed in fresh fixative overnight at $4^{\circ} \mathrm{C}$. For epoxy embedding, tissues were postfixed in $2 \% \mathrm{OsO} 4$ in $0.1 \mathrm{~m}$ phosphate buffer, dehydrated in an ascending series of ethanol, and embedded in epoxy. Semithin sections were stained with toluidine blue; thin sections were stained with lead citrate and uranyl acetate. For line 96, we examined 
semithin sections of animals at P158 (two $\mathrm{TG}^{-}$and two $\mathrm{TG}^{+}$). Color slides of representative images were scanned (Super Cool Scan;Nikon, Tokyo, Japan) and manipulated in Adobe Photoshop. Thin sections were examined with a Zeiss electron microscope.

Teased, osmicated fibers were prepared from one litter of P387 $c \times 32^{-/ Y}$ mice (two $\mathrm{TG}^{-}$and four $\mathrm{TG}^{+}$from line 90 ). After fixation and osmication as above, the nerves were placed in 33, 66, and $100 \%$ glycerol, each for at least $24 \mathrm{~h}$ at $45^{\circ} \mathrm{C}$ (Dyck et al., 1993a). Bundles of fibers were separated using fine forceps and a dissecting microscope, mounted in glycerin, and examined with differential interference optics with a Leica DMR microscope. To determine the proportion of normal and remyelinated axons, we counted myelinated axons that could be viewed for at least $2 \mathrm{~mm}$. Myelinated axons that had internodes of uniform length, with myelin sheaths that appeared normally thick for the axonal caliber, were considered normal. Myelinated axons had internodes are variable length, with myelin sheaths that were inappropriately thin for the axonal caliber, as well as supernumerary Schwann cells, were considered remyelinated. At least 100 myelinated fibers were examined in both the sensory and the motor branches of the femoral nerve.

Statistical analysis. For a quantitative analysis of demyelinated and remyelinated axons, digital images (OpenLab software; Improvision, Lexington, MA) were made of single transverse semithin sections femoral motor and sensory (saphenous) nerves. All demyelinated, remyelinated, and normally myelinated axons were counted by the same observer (S.S.S.) without knowledge of the animal's genotype. Axons larger than $1 \mu \mathrm{m}$ in diameter without a myelin sheath were considered demyelinated. Axons with myelin sheaths that were $<10 \%$ of the axonal diameter as well as myelinated axons that were surrounded by "onion bulbs" (circumferentially arranged Schwann cell processes and extracellular matrix) were considered remyelinated. The rest of the myelinated axons were considered to be normally myelinated. Repeated counts of one affected nerve were essentially identical (within 1\%). The proportion of demyelinated and remyelinated axons in $\mathrm{TG}^{+}$versus $\mathrm{TG}^{-}$animals was compared by the Wilcoxon rank-sum test (see Table 1). We also modeled the odds of observing an abnormally myelinated axon. In this context, odds were defined as the probability of an abnormally myelinated axon divided by the probability of a normally myelinated one. Odds ratios (ORs) were calculated using the Mantel-Haenszel statistic and the logit model; the Mantel-Haenszel statistic calculates ORs adjusted for or stratified by any confounding variables, and the logit model was used for this binomial outcome data because it also appropriately models probabilities (in the form of ORs). ORs were estimated using logit regression with adjustment for clustering. This adjustment changed the SEs and the values that depended on them including the $p$ value and confidence intervals.

\section{Results}

Generation of $c x 32$-null $\mathrm{TG}^{+}$mice

Figure 1 shows the design of our transgenic construct. Because transgenes made with genomic DNA are expressed at higher levels than those made with cDNA (Brinster et al., 1988; Palmiter et al., 1991), we used the human GJB1/CX32 genomic fragment containing exons $1 \mathrm{~b}$ and 2 and the intervening intron. Other derivates of this construct drive the expression of transgenes in myelinating Schwann cells (Abel et al., 1999; Pot et al., 2002; Leone et al., 2003). We generated three lines that expressed wild-type human $\mathrm{Cx} 32$ and selected the line (line 90) with the lowest expression of Cx32 protein (data not shown) for the experiments described below. To generate both $\mathrm{TG}^{+}$and $\mathrm{TG}^{-}$male mice that were also null at the endogenous $c \times 32 / G j b 1$ locus $\left(c \times 32^{-/ Y}\right), \mathrm{TG}^{+}$ male mice were crossed with $c \times 32^{-1-}$ female mice (Nelles et al., 1996). The genotypes of the mice $\left(\mathrm{TG}^{+}\right.$or $\mathrm{TG}^{-}$as well as $c x 32^{-/ \mathrm{Y}}$ or $c \times 32^{+/ Y}$ mice) were identified by PCR of genomic DNA (Abel et al., 1999). As expected, about one-half of the progeny were $\mathrm{TG}^{+}$mice, demonstrating that the TG was inherited in an autosomal pattern and that there was no excessive mortality in the either the $\mathrm{TG}^{+}$or $\mathrm{TG}^{-}$male mice (data not shown).
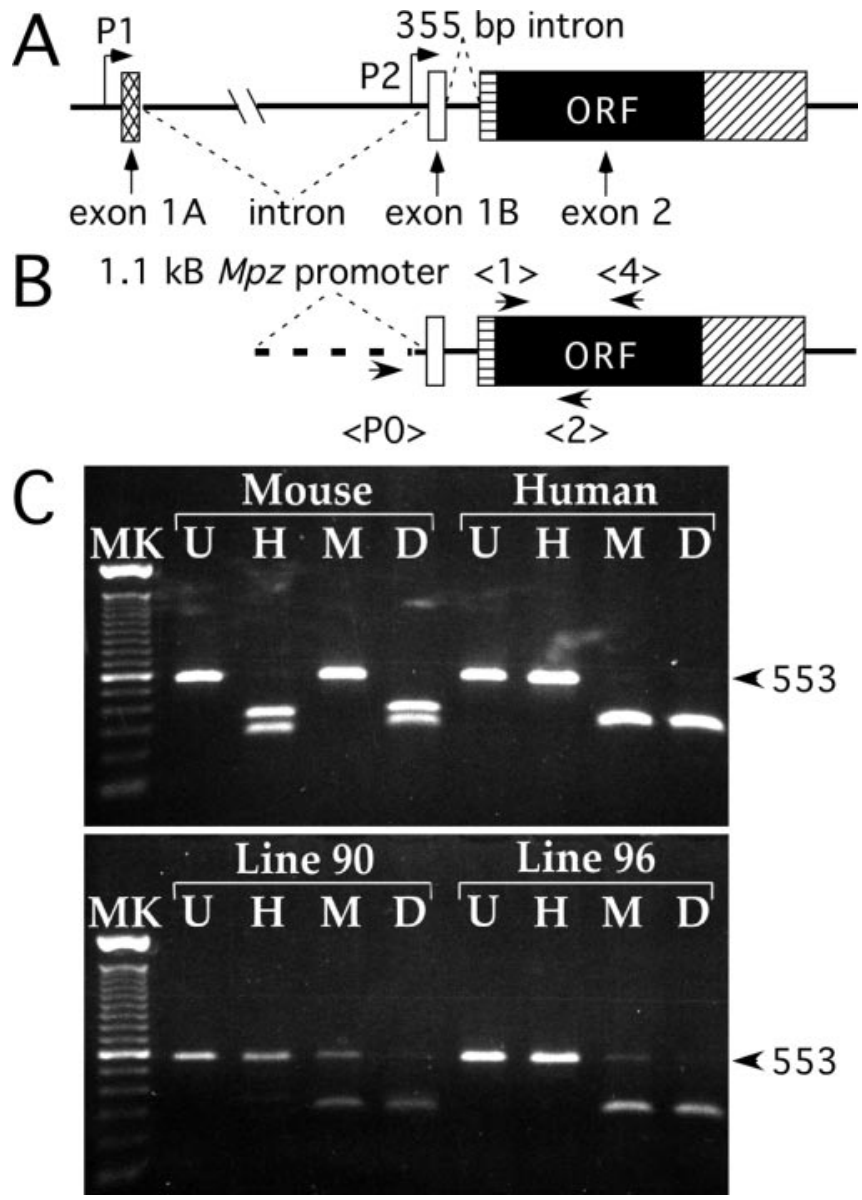

Figure 1. A rat $M p z$ promoter/GJB1 transgene cassette is expressed in peripheral nerve. $A$, The structure of the human $G J B 1 / C \times 32$ gene. In myelinating Schwann cells, $C \times 32$ transcripts are initiated from the $\mathrm{P} 2$ promoter; in the liver, transcripts are initiated from the P1 promoter (Neuhaus et al., 1995, 1996; Söhl et al., 1996). B, The structure of the transgene. The $1.1 \mathrm{kB}$ rat $\mathrm{Mpz} / \mathrm{PO}$ promoter is joined upstream of exon $1 \mathrm{~b}$ of the human $G J B 1 / C \times 32$ gene. The positions of the primer pairs used to amplify $\mathrm{CDNA}_{1}\langle 1\rangle$ and $\langle 4\rangle$ and $\langle\mathrm{PO}\rangle$ and $\langle 2\rangle$, are indicated. C, Analysis of endogenous versus transgene expression by semiquantitative RT-PCR. The top panel shows human/mouse $C \times 32 / C \times 32$ cDNA amplified with primers $(<1>$ and $<4>)$ that hybridize with a sequence that is identical in human and mouse $C \times 32 /(x 32$. The undigested (U) PCR product is $553 \mathrm{bp}$; Hhal (H) cuts mouse $\times 32$ but not human $(\times 32$, Mscl (M) cuts human CX32 but not mouse $C \times 32$; the double digestion $(D)$ proves that no full-length product remains. The bottom panel shows similarly digested RT-PCR products from adult transgenic sciatic nerve. Densitometric quantitation of the mouse- and human-specific bands in the Mscl-cut lane indicates that the ratio of transgene/human $C \times 32$ mRNA are $\sim 1$ and 3 for lines 90 and 96, respectively. MK, DNA size markers.

\section{Expression of transgenic and endogenous Cx32 mRNA}

To determine whether transgenic mRNA was expressed, we performed RT-PCR on peripheral nerves from single animals with transgene-specific primers (Fig. $1 B,<\mathrm{P} 0>$ and $<2>$ ). RT-PCR amplified a 517 bp product, predicted to be the RNA-specific product, without any amplification of genomic DNA (predicted to be a 872 bp product) from each cDNA sample (data not shown). The amplification of a $553 \mathrm{bp}$ product from the same cDNA samples with primers that hybridize to common nucleotide sequences that are identical in both human and mouse $C \times 32 /$ $c \times 32$ (Fig. $1 B,<1>$ and $<4>$ ), followed by restriction digestion, allowed a semiquantitative determination of the relative amount of transgene/human to endogenous/mouse Cx32 mRNA (Fig. 1C). Hha I uniquely cut the mouse cx32 cDNA, while MscI uniquely cut the human $C x 32 \mathrm{cDNA}$. Densitometric analysis of mouse- and human-specific bands within a single lane showed 
threefold more transgenic/human Cx32 cDNA compared with endogenous/mouse cx32 cDNA for line 96, while line 90 had approximately equal amounts. These experiments were performed on two animals from each line ( 5 weeks and 6 months of age) with the same results.

\section{Immunoblot analysis}

To determine whether transgenic/human Cx32 protein was expressed, we performed immunoblot analysis using an antiserum against the intracellular loop of Cx32 (Fig. 2). The sciatic nerves of $\mathrm{TG}^{+} \mathrm{Gjb1/c \times 32^{-/Y }}$ male mice (lane 1) contained bands of Cx32 monomers and dimers, respectively (Scherer et al., 1995). The amount of Cx32 (monomer and dimer) was higher in $\mathrm{TG}^{+}$ nerve than in wild-type nerve (lane 5). In addition, this antiserum recognized a lower molecular mass band in transgenic nerves, likely partially degraded Cx32 (perhaps caused by overexpression) or the result from a signal peptidase that cleaves the $\mathrm{N}$ terminus of Cx32 (Falk et al., 1994). In contrast, the liver from $\mathrm{TG}^{+}$(lane 2) or $\mathrm{TG}^{-}$(lane 4) mice, or the sciatic nerve from $\mathrm{TG}^{-}$mice (lane 5), did not contain $\mathrm{Cx} 32$. The bands that are found in cx32-null mice are "background bands" and do not represent $\mathrm{Cx} 32$. To show that these results are not confounded by unequal loading of the samples, the blot was reprobed for $\mathrm{P}_{0}$, and the gel was stained with Coomassie after transfer, as shown in Figure 2, $B$ and $C$, respectively. We obtained similar results from another set of animals and confirmed these results with a monoclonal antibody (against intracellular tail of Cx32; data not shown). Identical blots probed with secondary antibody only showed no background bands (data not shown).

\section{$\mathrm{TG}^{+}$myelinating Schwann cells but not oligodendrocytes express $\mathrm{Cx} 32$}

To determine whether the transgene was also expressed in oligodendrocytes, we examined the expression of Cx32 in sections of the spinal cord. To delineate the PNS/CNS boundary, we used an antibody against MOG, which labels the outer aspects of CNS but not PNS myelin sheaths (Brunner et al., 1989), and an antibody against NF-H, which labels both CNS and PNS axons. As shown in Figure 3C, a rabbit antiserum against the loop of $\mathrm{Cx} 32$ labeled myelinating Schwann cells in the ventral roots (vr) of $\mathrm{TG}^{+}$ $c \times 32^{-/ Y}$ mice but not label the spinal cord (s.c.) itself. In $\mathrm{TG}^{-}$ $c \times 32^{-/ Y}$ mice, there was no $\mathrm{Cx} 32$ staining in either the roots or in the CNS myelin sheaths (Fig. $3 B$ ), confirming the specificity of the Cx32 antibody, whereas wild-type mice had Cx32 in both locations (Fig. 3A). We observed the same results with another rabbit antiserum and a monoclonal antibody that were directed against the intracellular loop and the $\mathrm{C}$ terminus, respectively, of Cx32 (data not shown).

\section{The localization of human Cx32 in PNS myelin sheaths}

Human Cx32 is highly homologous to mouse Cx32, differing at only four amino acids in the extracellular loops (Scherer and Paul, 2004). Thus, it seemed plausible that human Cx32 would traffic like its murine counterpart, to the noncompact regions of the PNS myelin sheath. To determine the localization of human or mouse Cx32, we immunostained unfixed teased fibers from adult sciatic nerves. In wild-type mice, $\mathrm{Cx} 32$ was mainly localized to incisures and paranodes (Fig. 4A), with lesser amounts in the inner and outer mesaxons (Bergoffen et al., 1993; Scherer et al., 1995; Chandross et al., 1996; Balice-Gordon et al., 1998; Meier et al., 2004). No Cx32 immunoreactivity was seen in $\mathrm{TG}^{-} \mathrm{cx} 32^{-/ \mathrm{Y}}$ nerves, whereas the localization of other components, such as E-cadherin (Fig. $4 B$ ) and MAG (data not shown) was unaffected.

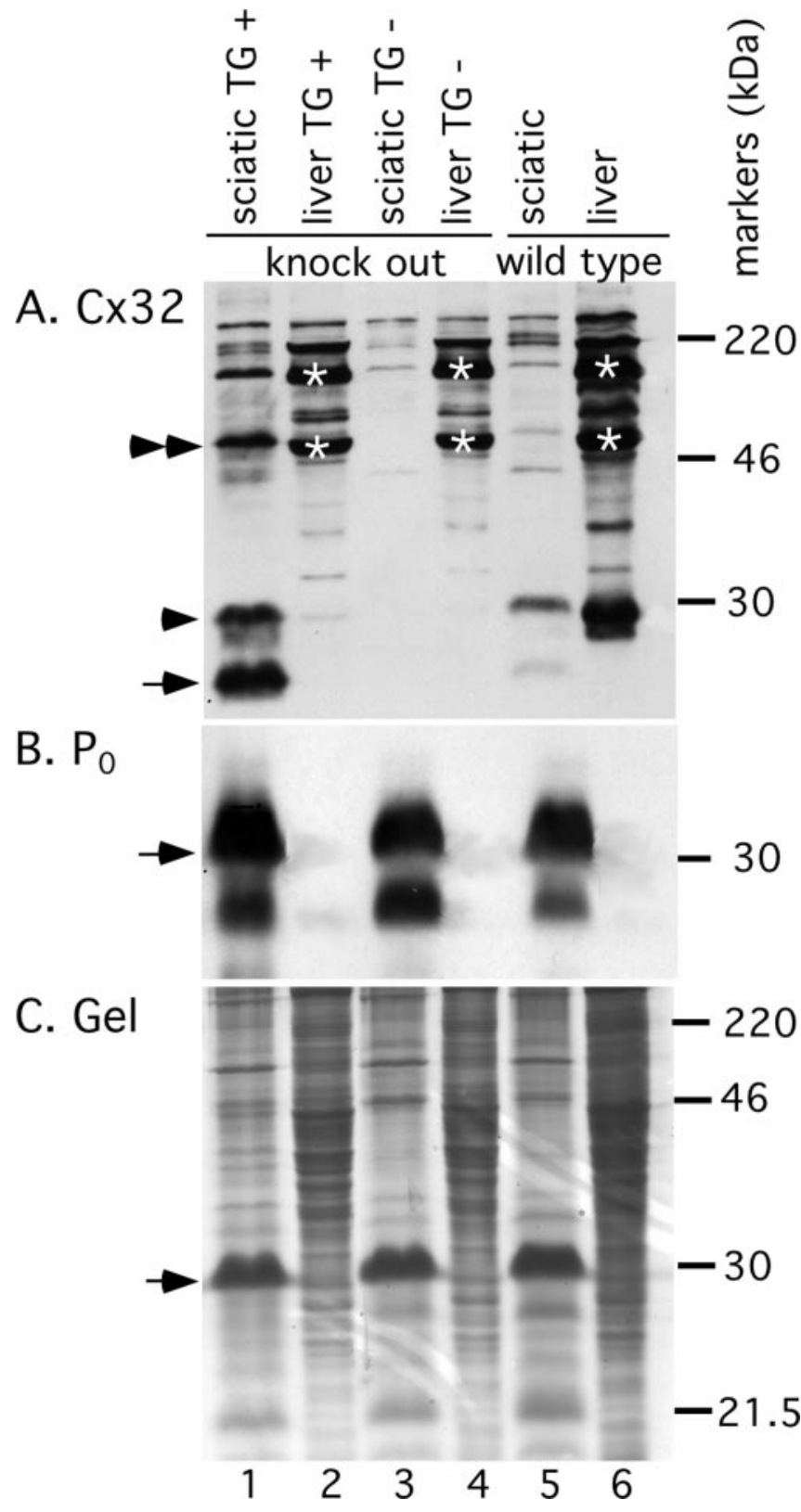

Figure 2. Expression of $\mathrm{C} x 32$ and $\mathrm{P}_{0}$ in peripheral nerve and liver. $A$, Immunoblot analysis of C $\times 32$. Protein extracts of sciatic nerve and liver from P445 $\mathrm{TG}^{+}$(lanes 1 and 2 ) and $\mathrm{TG}^{-}$(lanes 3 and 4) $c \times 32^{-/ \gamma}$ littermates and a P400 male wild-type mouse (lanes 5 and 6) were probed with a rabbit antiserum (Zymed) against the $(x 32$ intracellular loop (exposure time, $2 \mathrm{~min}$ ). The single and double arrowheads indicate $\mathrm{C} \times 32$ monomers and dimers, respectively. Note that C $\times 32$ detected in the sciatic nerve but not in the liver of $\mathrm{TG}^{+}$mice (compare lanes 1 and 2 ), that there is relatively more $\left(x 32\right.$ in TG ${ }^{+}$mice than in wild-type mice (compare lanes 1 and 5$)$, and that some $\mathrm{C} \times 32$ appears to be partially degraded (lane 1, arrow). Any bands that are found in $\left(\mathrm{TG}^{-}\right)$(x)32-null liver and nerve are nonspecific, such as the prominent bands in liver (asterisks). $B$, Reprobing the same blot with a rabbit antiserum against $P_{0}$ demonstrates comparable levels of $P_{0}$ (arrow) in all nerves (exposure time, $20 \mathrm{~s}$ ). C, Coomassie-stained gel after transfer shows loading of sciatic nerve and liver samples. The position of $\mathrm{P}_{0}$ is indicated (arrow).

In $\mathrm{TG}^{+} c \times 32^{-/ Y}$ mice, in contrast, there was pronounced $\mathrm{Cx} 32$ immunostaining in paranodes and incisures, including aggregates that were much larger than those seen in wild-type nerves (Fig. 4C). Similar aggregates of $\mathrm{Cx} 32$ were colocalized with strands of E-cadherin staining marking the outer mesaxons (Fannon et al., 1995). These data show that although human Cx32 appears to be overexpressed in this transgenic line, it is properly localized. 


\section{A Cx32 transgene prevents demyelination in $c x 32^{-/ Y}$ mice}

The above results demonstrate that the 1.1 $\mathrm{kB}$ rat $M p z$ promoter efficiently drives the expression of the human GJB1 gene in myelinating Schwann cells, resulting in moderately higher levels of transgenic/human $\mathrm{Cx} 32$ protein than endogenous/murine Cx32 in wild-type mice. To determine whether selectively expressing normal human Cx32 in myelinating Schwann cells prevents demyelination in $c \times 32^{-/ Y}$ mice, we analyzed semithin sections of the sciatic and femoral nerves, as well as the cauda equina (the ventral and dorsal roots) from $\mathrm{TG}^{+}$and $\mathrm{TG}^{-} c \times 32^{-/ Y}$ littermates, at P158, P250, and P365. These ages were selected because demyelination begins around $\mathrm{P} 90$ in $c \times 32^{-/ Y}$ mice and becomes prominent by P158 (Anzini et al., 1997; Scherer et al., 1998). Because myelinated motor fibers are much more affected than are myelinated sensory fibers in $c \times 32^{-/ Y}$ mice, we focused on the femoral motor nerve because it contains a higher proportion of motor axons than does the sciatic nerve (60 vs $20 \%$ of myelinated axons) (Boyd and Davey, 1968; Swett et al., 1986).

At P158 and P250, the femoral nerves (Figs. $5 A, C, 6 A$ ), ventral roots (Fig. 6C), and sciatic nerves (data not shown) of $\mathrm{TG}^{+} c \times 32^{-/ \mathrm{Y}}$ mice looked normal. There were rare demyelinated axons (axons without a myelin sheath; $>1 \mu \mathrm{m}$ in diameter) or remyelinated axons (axons $>1$ $\mu \mathrm{m}$ in diameter with inappropriately thin myelin sheaths for their axonal caliber, often associated with onion bulbs, crescents of Schwann cells processes). In contrast, in their age-matched, $\mathrm{TG}^{-}$littermates, there were numerous demyelinated axons, remyelinated axons, and onion bulbs, as well as occasional myelin sheaths that were disrupted, split, or separated from their axon and macrophages containing myelin debris and/or lipid droplets within the endoneurium or apposed to the inner surface of the perineurium (Fig. 6B,D), as described previously (Anzini et al., 1997; Scherer et al., 1998). These pathological findings were much more prominent in motor axons, in the motor but not the sensory branch of the femoral nerve, in fascicles of large myelinated axons (presumably motor axons) in the sciatic nerve, and in the ventral/motor (Fig. 6D) but not the dorsal/sensory (data not shown) lumbar roots, except that onion bulbs were not prominent in the roots. At P365, however, there appeared to be more demyelinated and remyelinated axons in than in younger $\mathrm{TG}^{+} \mathrm{c} \times 32^{-/ Y}$ mice, although still not as many as in $\mathrm{P} 365 \mathrm{TG}^{-} c \times 32^{-/ Y}$ mice (Fig. $5 E, F$ ). This increase in pathologically affected myelinated axons was more pronounced in the

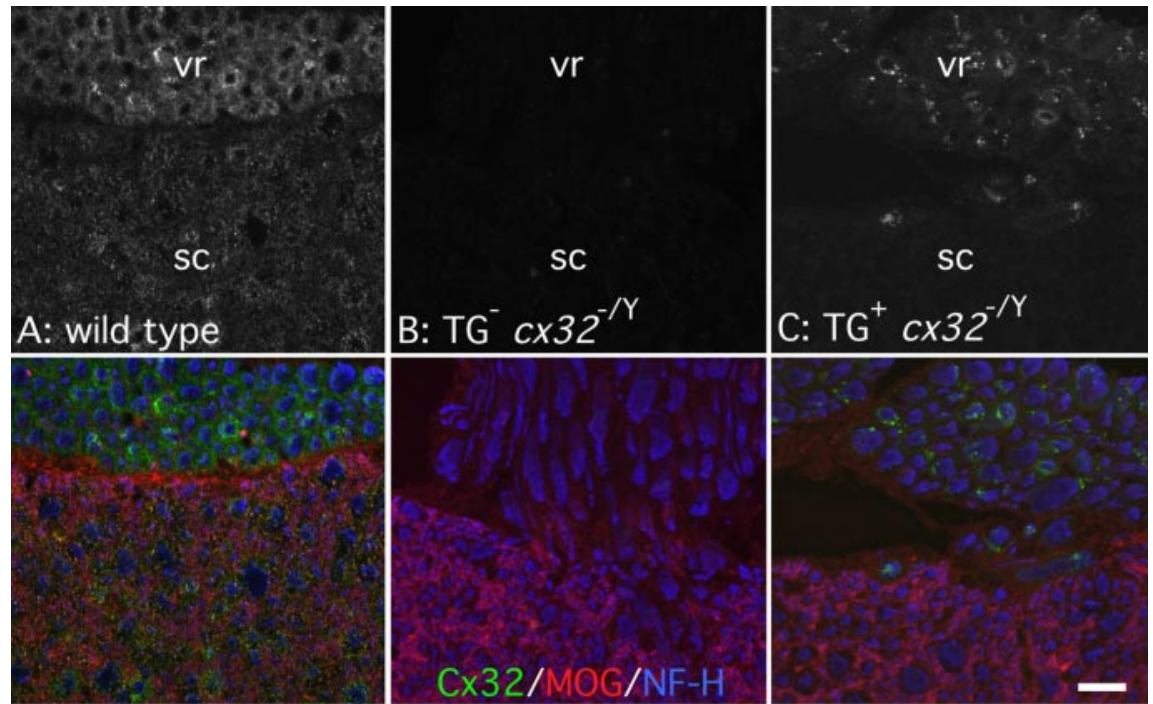

Figure 3. Myelinating Schwann cells but not oligodendrocytes express a Mpz-CX32 transgene. These are confocal images of unfixed s.c. and attached vr from a P400 wild-type mouse $(A)$ and P385 TG ${ }^{-}(B)$ and TG ${ }^{+}(C) C \times 32^{-/ \gamma}$ littermates. The sections were labeled with a rabbit antiserum against the cytoplasmic loop of $\mathrm{Cx32}$ (Chemicon), a mouse monoclonal antibody against MOG, and a rat monoclonal antibody against NF-H. The top panels depict Cx32 staining alone; the bottom panels show merged images of $\mathrm{Cx} 32$ (green), MOG (red), and NF-H (blue). Note that MOG is localized to the CNS myelin sheaths in the ventral funiculus; that NF-H is found in both CNS and PNS axons; and that $\mathrm{Cx32}$ is present in both the roots and the cord of wild-type mice $(A)$, in neither the roots nor the cord of TG ${ }^{-}$mice $(B)$, and in the roots but not in the cord of $\mathrm{TG}^{+}$mice $(C)$. The exposure to visualize $(x 32$ immunoreactivity for $B$ was as long as that for $C$. Scale bar, $20 \mu \mathrm{m}$.
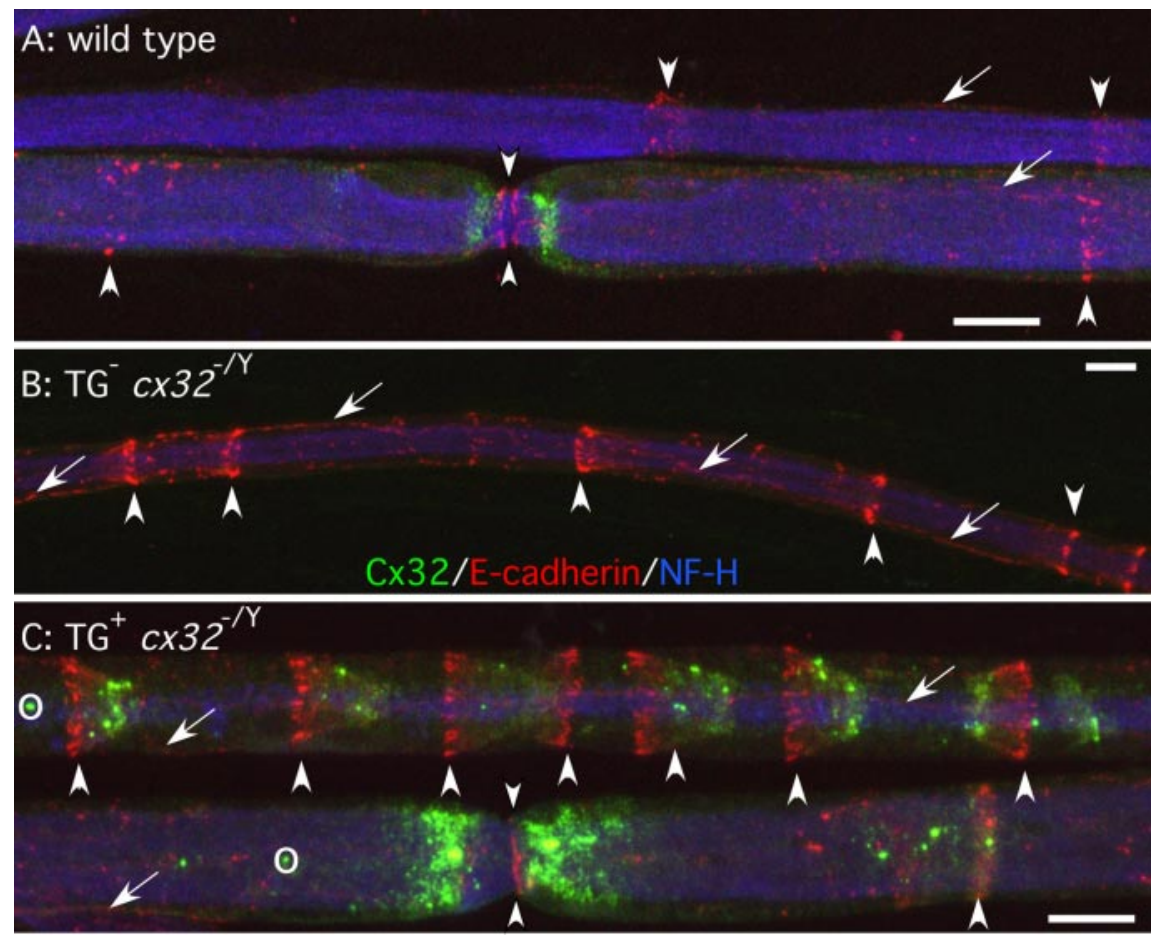

Figure 4. Human $\mathrm{Cx} 32$ localizes to noncompact myelin. These are confocal images of unfixed teased sciatic nerve fibers from a P400 wild-type mouse $(A)$ and P385 TG ${ }^{-}(B)$ and TG ${ }^{+}(C) C 32^{-/ \gamma}$ littermates. The fibers were immunostained with a mouse monoclonal antibody against $\mathrm{C} \times 32$, a rabbit antiserum against E-cadherin, and a rat monoclonal antibody against NF- $\mathrm{H}$, as indicated. Apposed arrowheads mark nodes, which are flanked by (x32-positive paranodes in wild-type and TG ${ }^{+}$mice. Prominent E-cadherin staining is seen in incisures (arrowheads) and outer mesaxons (arrows). The large aggregates of $C \times 32$ in the outer mesaxons (circled), incisures, and paranodes of $c \times 32^{-N} \mathrm{TG}^{+}$fibers $(C)$ are not seen in wild-type fibers (A). Scale bars, $10 \mu \mathrm{m}$.

femoral motor branch (Fig. $5 E, F)$ than in the sciatic nerve, ventral roots, or dorsal roots (Fig. 6 and data not shown).

To confirm and extend the above findings, we teased osmicated fibers from a litter of $1-y r-o l d ~ c x 32^{-/ Y}$ mice (four TG ${ }^{+}$and 


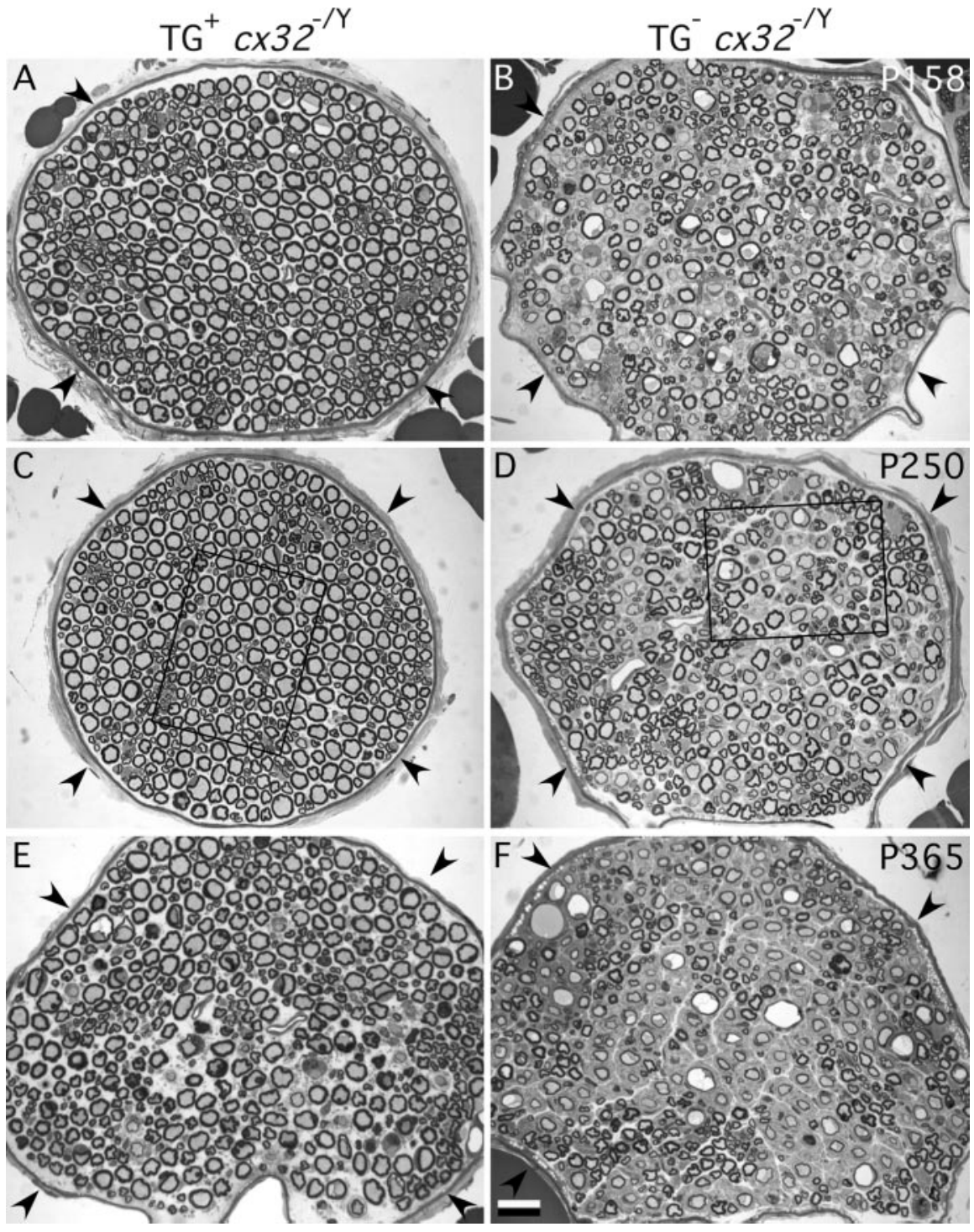

Figure 5. Transgenic expression of human $C \times 32$ prevents demyelination. These are images of semithin sections of femoral motor nerve from $\mathrm{TG}^{+}$and $\mathrm{TG}^{-}$mice at P158, P250, and P365 $\mathrm{C} 32^{-/ \mathrm{V}}$ littermates. The $\mathrm{TG}^{+}$nerves look normal at P158 and $P 250$, but there are 30 de/remyelinated axons in the P365 nerve. The number of de/remyelinated axons at P158, P250, and P365 in TG ${ }^{-}$nerves was higher at every age $(135,166$, and 297 , respectively). Arrowheads mark the perineurium. The areas outlined by the rectangles are enlarged in Figure 6, $A$ and $B$. Scale bar, $20 \mu \mathrm{m}$.

two $\mathrm{TG}^{-}$). A $1 \mathrm{~cm}$ segment of the femoral motor branch was teased into small bundles and examined by light microscopy without knowledge of the animal's genotype. Nerves from two animals had a modest proportion of remyelinated axons (at least $20 \%$ of myelinated fibers; $>100$ fibers examined per animal), whereas remyelinated axons were relatively scarce in the other four animals (between 1 and 5\%; >100 fibers examined per animal). These results proved to be in complete accord with the genotypes of the mice; $\mathrm{TG}^{+}$mice had few remyelinated axons. In all animals, the largest axons were the most affected, probably because they contain the highest proportion of motor axons. Most large myelinated axons from $\mathrm{TG}^{+}$mice had uniformly spaced, long internodes with myelin sheaths that appeared to be appropriately thick for the axonal caliber (Fig. 7B). In contrast, many large myelinated fibers from $\mathrm{TG}^{-}$mice had internodes of variable lengths, some of which had abnormally thin myelin sheaths, often with associated supernumerary nuclei and Schwann cell processes (Fig. 7A). Some of the myelin sheaths of these remyelinated axons were split or separated from their axon, as noted previously (Scherer et al., 1998). Furthermore, most myelin internodes belonging to the same fiber appeared be either normal or affected, indicating that single fibers are affected over most of their length.

We suspected that the small myelinated axons, and even many of the unaffected large myelinated sensory fibers in the femoral motor branch, were unaffected because they are mainly sensory axons. To pursue this issue, we also examined teased fibers from the sensory branch of the femoral nerve, the saphenous nerve. In both $\mathrm{TG}^{+}$and $\mathrm{TG}^{-}$mice, nearly all (>99\%) of myelinated fibers in the saphenous nerve were normally myelinated (data not shown). These results, taken together, provide additional evidence that $c \times 32^{-/ Y}$ mice have a demyelinating neuropathy that primary affects motor axons (Anzini et al., 1997; Scherer et al., 1998). As the disease progresses, motor axons are demyelinated and remyelinated throughout their length, and this can be mostly prevented or at least delayed by the expression of normal human Cx32 in myelinating Schwann cells.

\section{Statistical analysis}

The above data demonstrate that expression of human Cx32 can prevent/delay the onset of demyelination in motor axons of $c \times 32^{-/ Y}$ mice. To substantiate this point, we performed a quantitative analysis of the femoral nerve, because it has a tractable number of axons for counting and a partial separation of motor and sensory axons. We counted all of the demyelinated, remyelinated, and normally myelinated axons in a single transverse section of the femoral sensory and motor branches at P158, P250, and P365, combining the counts from the left and right sides for individual animals where possible. The image in Figure $6 B$ depicts examples of what we considered to be demyelinated and remyelinated axons. As shown in Table 1, there were essentially no demyelinated or remyelinated axons in the sensory branch, as expected (Anzini et al., 1997; Scherer et al., 1998), whereas the motor branch in $\mathrm{TG}^{-}$mice had more abnormal fibers (demyelinated or remyelinated) than did those in $\mathrm{TG}^{+}$ mice (Fig. 8). By the Wilcoxon rank-sum test, the overall difference in the proportion of abnormally myelinated fibers between $\mathrm{TG}^{-}$and $\mathrm{TG}^{+}$was 0.0012 , but this was less compelling at any individual time point because of small sample sizes.

We also modeled the odds of observing an abnormally myelinated axon, defining odds as the probability of an abnormally myelinated axon divided by the probability of a normally myelinated one. An OR of 1.0 means the odds of the outcome occurring is not different than the odds of the outcome not occurring. By estimating the ORs with the logit regression model, we could adjust the logit model to account for the clustering of data within animals, in addition to controlling for confounders and stratify- 
ing the analyses when there were significant interactions. Table 2 shows the ORs of abnormally myelinated axons, separately by age group, from the logit regression model with an interaction for age and adjustment for clustering of fibers within mice. Adjustment for clustering only affected the SEs and the values that depended on them, including the $p$ value and confidence intervals. The odds of observing an abnormally myelinated axon in the P158 $\mathrm{TG}^{-}$group was 90 times higher than the odds of finding one in the P158 $\mathrm{TG}^{+}$ group $(p<0.00)$; the OR at $\mathrm{P} 250$ was also large $(67 ; p<0.00)$. The $\mathrm{OR}$ at $\mathrm{P} 365$ was 8 $(p<0.00)$, still large, but less than at the younger ages. Additional comparisons showed that the OR for the P158 group was significantly different from that of the P365 group ( $p=0.003)$ but not more than that of the P250 group ( $p=0.711$ ). These analyses indicate that there was not one overall OR that characterized a genotype $\left(\mathrm{TG}^{-}\right.$or $\left.\mathrm{TG}^{+}\right)$; the relationship differed depending on age. The interaction between age and genotype was statistically significant (likelihood ratio test; $\chi^{2}=$ $65.99 ; p>0.00)$; the effect of genotype varied significantly by age.

\section{Discussion}

Is CMT1X primarily a demyelinating or axonal neuropathy?

According to criteria that were developed to distinguish the demyelinating (CMT1) from the axonal (CMT2) forms of CMT (Harding and Thomas, 1980), CMT1X is more like CMT2 than CMT1. Nerve conduction velocities are typically in 30-40 $\mathrm{m} / \mathrm{s}$ in affected males and $30-50 \mathrm{~m} / \mathrm{s}$ in affected females (Nicholson and Nash, 1993; Rouger et al., 1997; Birouk et al., 1998; Hahn et al., 1999; Senderek et al., 1999); this is faster than the $20 \mathrm{~m} / \mathrm{s}$ typically seen in CMT1A patients (Birouk et al., 1997). In addition, electrophysiological studies pronounced loss of distal motor axons in CMT1X (Rozear et al., 1987; Hahn et al., 1990, 1999; Nicholson and Nash, 1993; Rouger et al., 1997; Birouk et al., 1998; Senderek et al., 1999). Finally, nerve biopsies show more axonal loss and less remyelination than is typically seen in CMT1A or CMT1B (Sander et al., 1998; Hahn et al., 2001). These data have lead to the frequent supposition that CMT1X is an axonal neuropathy (Hahn et al., 1990; Timmerman et al., 1996; Birouk et al., 1998).

Other data indicate that CMT1X is primarily a demyelinating neuropathy, albeit with important secondary axonal loss. Myelinating Schwann cells express Cx32, and its expression appears to be regulated at the level of transcription in concert with many myelin-related genes (Scherer et al., 1995; Chandross et al., 1996; Söhl et al., 1996). Cx32 is prominently localized in noncompact myelin and may help form a radial pathway that mediates the diffusion of small molecules and ions directly across the layers of the myelin sheath (Balice-Gordon et al., 1998). Finally, demyelination is the first pathological alteration $c x 32$-null mice, preced- ing axonal loss (Anzini et al., 1997; Scherer et al., 1998). Why axonal loss appears to be more pronounced in CMT1X that in other kinds of CMT1 that have even slower conduction is unknown; this discrepancy underscores our lack of understanding of the mechanisms of axonal loss in demyelinating diseases.

To address this issue, we selectively expressed human Cx32 in myelinating Schwann cells of $c \times 32^{-/ Y}$ mice. The human and mouse Cx32 proteins differ at four amino acids (Scherer and Paul, 2004), but none of these are known to be affected by missense mutations that cause CMT1X (http://www.molgen.ua.ac.be/CMTMutations/ DataSource/MutByGene.cfm), so that human and mouse proteins may be functionally equivalent. Using a rat $M p z$ promoter, we were able to show that mouse myelinating Schwann cells express human $\mathrm{Cx} 32$, that human $\mathrm{Cx} 32$ is properly localized to incisures and paranodes, and that human Cx32 "rescues" the demyelinating phenotype in $c \times 32^{-/ Y}$ Schwann cells. That the selective expression of human Cx32 in myelinating Schwann cells is sufficient to rescue the phenotype of $c \times 32^{-/ Y}$ mice indicates that demyelination initiates the complex events of neuropathy, which includes immune-mediated damage and axonal loss (Kobsar et al., 2002, 2003). 

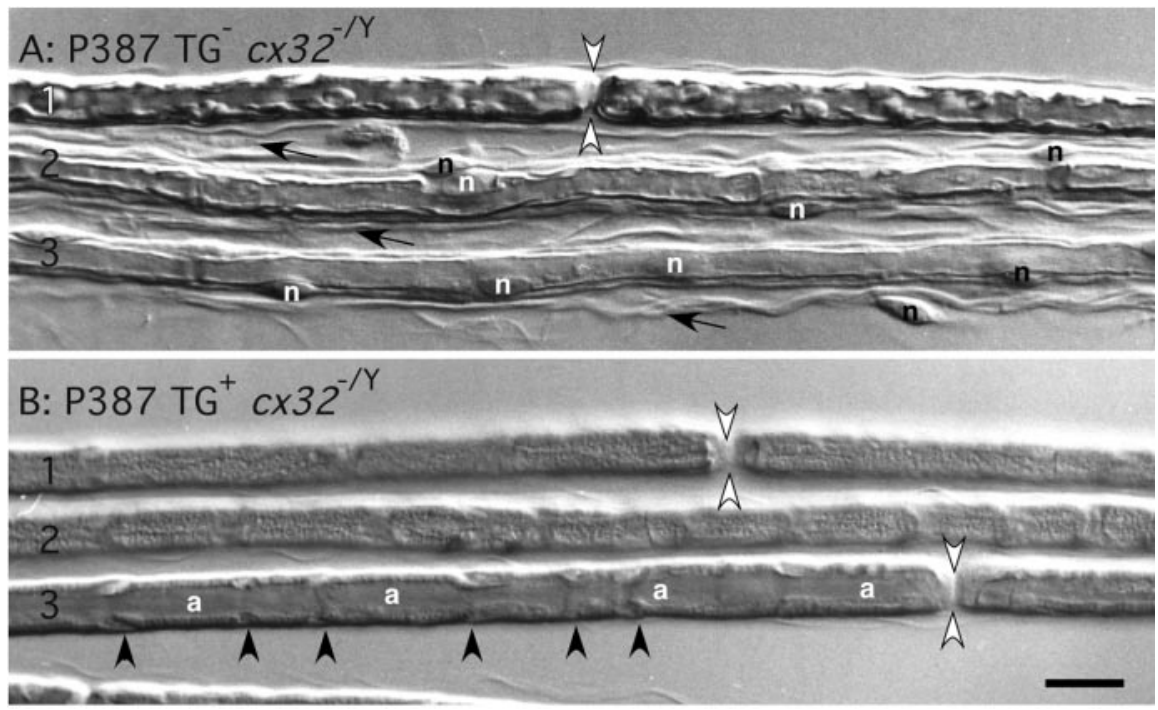

Figure 7. Transgenic expression of human Cx32 prevents segmental demyelination. These are differential interference contrast images of teased fibers from osmicated femoral motor branches of $\mathrm{TG}^{-}{ }^{-}$or $\mathrm{TG}^{+} \mathrm{P} 387 \mathrm{C \times 32} 2^{-/ \gamma}$ littermates. In each panel, three teased fibers are labeled (1-3); apposed arrowheads mark the nodes of normal-appearing myelinated axons. Note the one normal-appearing myelinated axon (1) in the $\mathrm{TG}^{-}{ }^{-}$root, along with two axons with abnormally thin myelin sheaths (2 and 3 ) that are associated with supernumerary Schwann cell nuclei ( $\mathrm{n}$ ) and their cellular processes (arrows). All three $\mathrm{TG}^{+}$teased fibers appear normal; the axon (a) and incisures (arrowheads) are clearly seen in one fiber in the correct focal plane (3). Scale bar, $10 \mu \mathrm{m}$.

\section{Cell autonomy and the pathogenesis of demyelinating neuropathies}

Dominant mutations in PMP22, MPZ, EGR2, LITAF/SIMPLE, and GJB1, as well as recessive mutations in GDAP1, MTMR2, MTMR13, KIAA1985, NDRG1, PRX, and EGR2 cause demyelinating neuropathies http://www.molgen.ua.ac.be/CMTMutations/DataSource/MutByGene.cfm). Myelinating Schwann cells express these genes, many of which (PMP22, MPZ, EGR2, GJB1/ $C \times 32, N D R G 1$, and $P R X)$ appear to be similarly regulated at the level of transcription by axon-Schwann cell interactions (Wrabetz et al., 2004). Mutations in these genes have been considered to have cell-autonomous effects that result in demyelination, but some of these genes (PMP22, GJB1/Cx32, GDAP1, MTMR2,
MTMR13) are also expressed by neurons (Suter and Scherer, 2003). A formal evaluation regarding whether neuronal expression of these genes contributes to the pathogenesis of these neuropathies, as we have shown here for $\mathrm{Cx} 32$, remains to be performed.

\section{Effects of Cx32 overexpression}

By immunoblotting and immunostaining, transgenic/human Cx32 was overexpressed in myelinating Schwann cells compared with the endogenous/mouse $\mathrm{Cx} 32$. The cause of this overexpression is unclear, because the steady-state levels of transgenic and endogenous mRNA appeared to be similar. The larger than normal aggregates of $\mathrm{Cx} 32$ could be the cause or the result of overexpressed protein. A cx32-null background ameliorates the effect of Cx32 overexpression, and breeding line 90 or 96 into a wild-type background causes a gain-of-function phenotype (splitting of the myelin sheath) (L. J. B. Jeng, unpublished observations). Wrabetz et al. (2000) have reported a similar experience with transgenic lines that overexpress $\mathrm{P}_{0}$; there is an "overexpression phenotype" that is partially ameliorated by breeding the transgene into a Mpz-null background.

\section{Transgenic models of CMT1X}

The ability to selectively express a transgene in myelinating Schwann cells provides a straightforward means of determining the effects of various mutants that cause CMT1X. Given the large number of GJB1 mutations, this strategy is much more efficient than "knocking in" the corresponding mutation. We have used the $M p z-C \times 32$ construct to express other mutations as transgenes: 175 frameshift (Abel et al., 1999), Arg142Trp (Jeng, un-

Table 1. Quantitative analysis of demyelinated and remyelinated axons

\begin{tabular}{|c|c|c|c|c|c|c|c|c|}
\hline & \multicolumn{3}{|l|}{ Sensory branch } & \multicolumn{5}{|l|}{ Motor branch } \\
\hline & Demyelinated & Remyelinated & Total & Demyelinated & Remyelinated & Total & Abnormal & Wilcoxon \\
\hline $\mathrm{P} 158 \mathrm{TG}^{+}$ & 0 & 0 & 1880 & 0 & 0 & 1334 & 0 & \\
\hline P158 $\mathrm{TG}^{+}$ & n.a. & n.a. & n.a. & 0 & 1 & $557^{b}$ & 0.0017 & \\
\hline P158 $\mathrm{TG}^{+}$ & n.a. & n.a. & n.a. & 0 & 2 & $604^{b}$ & 0.0033 & \\
\hline $\mathrm{P} 158 \mathrm{TG}^{-}$ & 0 & 0 & $784^{b}$ & 72 & 63 & 1085 & 0.12 & \\
\hline P158 $\mathrm{TG}^{-}$ & 0 & 0 & $847^{b}$ & 7 & 43 & $564^{b}$ & 0.089 & \\
\hline $\mathrm{P} 158 \mathrm{TG}^{-}$ & 0 & 0 & $866^{b}$ & 3 & 29 & $574^{b}$ & 0.056 & 0.0495 \\
\hline $\mathrm{P} 50 \mathrm{TG}^{+}$ & 0 & 0 & 1602 & 0 & 2 & 1066 & 0.0018 & \\
\hline${\mathrm{P} 250 \mathrm{TG}^{+}}^{+}$ & 0 & 0 & $860^{b}$ & 1 & 3 & 1025 & 0.0039 & \\
\hline $\mathrm{P}^{-} 50 \mathrm{TG}^{-}$ & 0 & 0 & $1394^{a}$ & 13 & 153 & 1010 & 0.16 & \\
\hline $\mathrm{P}^{2} 50 \mathrm{TG}^{-}$ & n.a. & n.a. & n.a. & 11 & 73 & $535^{b}$ & 0.16 & 0.12 \\
\hline P365 $\mathrm{TG}^{+}$ & 0 & 0 & 1271 & 8 & 16 & 1078 & 0.022 & \\
\hline P365 $\mathrm{TG}^{+}$ & 0 & 0 & 1153 & 17 & 34 & 1166 & 0.044 & \\
\hline P365 $\mathrm{TG}^{+}$ & 0 & 0 & $597^{b}$ & 13 & 17 & 990 & 0.030 & \\
\hline P365 $\mathrm{TG}^{-}$ & 0 & 0 & $861^{b}$ & 27 & 155 & 1144 & 0.16 & \\
\hline P365 $\mathrm{TG}^{-}$ & 1 & 1 & 1231 & 35 & 262 & 1102 & 0.27 & 0.083 \\
\hline
\end{tabular}

This table gives the number of demyelinated and remyelinated axons, as well as the total (normal, demyelinated, and remyelinated) number of myelinated axons in the femoral sensory and motor branches. When both the left and the right nerves were available for individual animals, the numbers were combined. For the motor branch, the proportion of abnormally myelinated axons is shown, as well as a statistical comparison (Wilcoxon rank-sum test) between $\mathrm{TG}^{+}$and $\mathrm{TG}^{-}$ mice at each time point; the overall difference was 0.0012 .

n.a., Not available.

${ }^{a}$ Incomplete nerve.

${ }^{b}$ The left or right nerve could not be counted. 


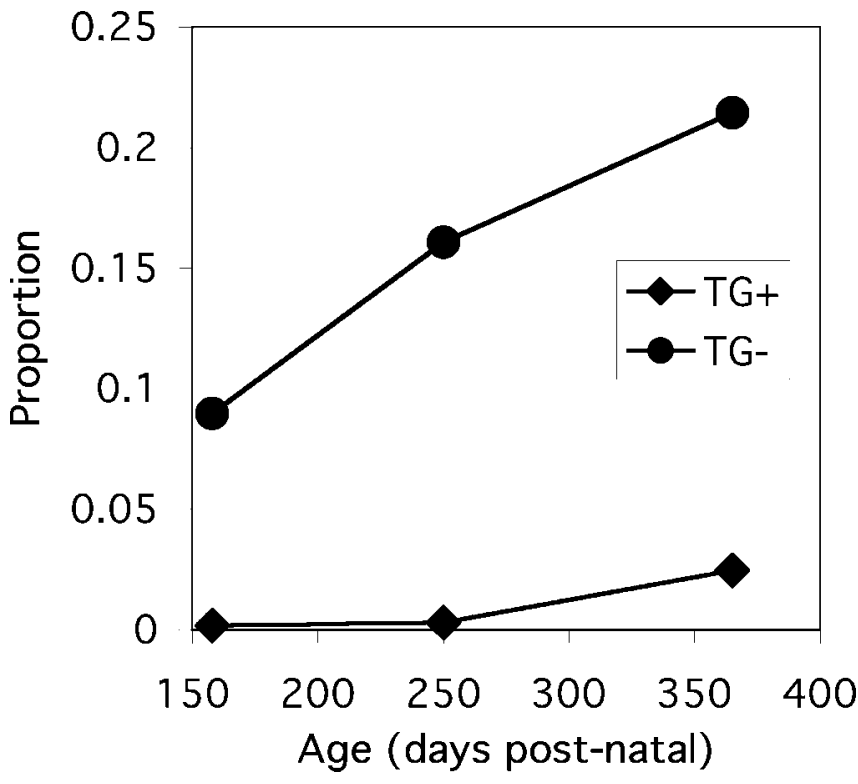

Figure 8. The proportion of abnormally myelinated axons in $\mathrm{TG}^{-}$or $\mathrm{TG}^{+}$femoral motor nerves. This plot shows the proportion of abnormally myelinated axons in the femoral motor nerves at P158, P250, and P365. The means are shown at each age, separately for $\mathrm{TG}^{-}{ }^{-}$and $\mathrm{TG}^{+}$ animals.

Table 2. 0dds ratios for abnormally myelinated fibers for $\mathrm{TG}^{-}$and $\mathrm{TG}^{+}$, stratified by age group and adjusted for clustering

\begin{tabular}{llllll}
\hline Age & Odds ratio & Robust SE & $z$ & $p>Z$ & $95 \%$ Confidence interval \\
\hline P158 & 89.9 & 66.9 & 6.04 & 0.000 & $20.9-387$ \\
P250 & 67.1 & 17.4 & 16.2 & 0.000 & $40.3-112$ \\
P365 & 8.08 & 2.41 & 7.01 & 0.000 & $4.50-14.5$ \\
\hline
\end{tabular}

published observations), Cys280Gly, and Ser281stop (S. Scherer, unpublished observations); each of these has distinct effects from wild-type $\mathrm{Cx} 32$. Because human $\mathrm{Cx} 32$ can substitute for mouse $\mathrm{Cx} 32$, the unique effects of these mutations can be ascribed to the mutations themselves.

\section{References}

Abel A, Bone LJ, Messing A, Scherer SS, Fischbeck KH (1999) Studies in transgenic mice indicate a loss of connexin32 function in X-linked Charcot-Marie-Tooth disease. J Neuropathol Exp Neurol 58:702-710.

Anzini P, Neuberg DH-H, Schachner M, Nelles E, Willecke K, Zielasek J, Toyka K, Suter U, Martini R (1997) Structural abnormalities and deficient maintenance of peripheral nerve myelin in mice lacking the gap junction protein connexin32. J Neurosci 17:4545-4561.

Balice-Gordon RJ, Bone LJ, Scherer SS (1998) Functional gap junctions in the Schwann cell myelin sheath. J Cell Biol 142:1095-1104.

Bennett SAL, Arnold JM, Chen JH, Stenger J, Paul DL, Roberts DCS (1999) Long-term changes in connexin32 gap junction protein and mRNA expression following cocaine self-administration in rats. Eur J Neurosci 11:3329-3338.

Bergoffen J, Scherer SS, Wang S, Oronzi-Scott M, Bone L, Paul DL, Chen K, Lensch MW, Chance P, Fischbeck K (1993) Connexin mutations in X-linked Charcot-Marie-Tooth disease. Science 262:2039-2042.

Birouk N, Gouider R, Le Guern E, Gugenheim M, Tardieu S, Maisonobe T, Le Forestier N, Agid Y, Brice A, Bouche P (1997) Charcot-Marie-Tooth disease type $1 \mathrm{~A}$ with $17 \mathrm{p} 11.2$ duplication-clinical and electrophysiological phenotype study and factors influencing disease severity in 119 cases. Brain 120:813-823.

Birouk N, Le Guern E, Maisonobe T, Rouger H, Gouider R, Gugenheim M, Tardieu S, Gugenheim M, Routon MC, Leger JM, Agid Y, Brice A, Bouche P (1998) X-linked Charcot-Marie-Tooth disease with connexin $32 \mathrm{mu}$ - tations-clinical and electrophysiological study. Neurology 50:1074-1082.

Boyd IA, Davey MR (1968) Composition of peripheral nerves, p 57. Edinburgh: Livingstone.

Brinster RL, Chen HY, Trumbauer ME, Yagle MK, Palmiter RD (1985) Factors affecting the efficiency of introducing foreign genes into mice by microinjecting eggs. Proc Natl Acad Sci USA 82:4438-4442.

Brinster RL, Allen JM, Behringer RR, Gelinas RE, Palmiter RD (1988) Introns increase transcriptional efficiency in transgenic mice. Proc Natl Acad Sci USA 85:836-840.

Brunner C, Lassmann H, Waehneldt TV, Matthieu J-M, Linington C (1989) Differential ultrastructural localization of myelin basic protein, myelin/ oligodendrocyte glycoprotein, and 2',3'-cyclic nucleotide $3^{\prime}$ phosphodiesterase in the CNS of adult rats. J Neurochem 52:296-304.

Chandross KJ, Kessler JA, Cohen RI, Simburger E, Spray DC, Bieri P, Dermietzel R (1996) Altered connexin expression after peripheral nerve injury. Mol Cell Neurosci 7:501-518.

D’Urso D, Brophy PJ, Staugaitis SM, Gillespie CS, Frey AB, Stempak JG, Colman DR (1990) Protein zero of peripheral nerve myelin: biosynthesis, membrane insertion, and evidence for homotypic interaction. Neuron 4:449-460.

Dyck PJ, Giannini D, Lais A (1993a) Pathologic alterations of nerves. In: Peripheral neuropathy, Ed 3 (Dyck PJ, Thomas PK, Griffin JW, Low PA, Poduslo JF, eds), pp 514-595. Philadelphia: Saunders.

Dyck PJ, Chance P, Lebo R, Carney JA (1993b) Hereditary motor and sensory neuropathies. In: Peripheral neuropathy, Ed 3 (Dyck PJ, Thomas PK, Griffin JW, Low PA, Poduslo JF, eds), pp 1094-1136. Philadelphia: Saunders.

Falk MM, Kumar NM, Gilula NB (1994) Membrane insertion of gap junction connexins: polytopic channel forming membrane proteins. J Cell Biol 127:343-355.

Fannon AM, Sherman DL, Ilyina-Gragerova G, Brophy PJ, Friedrich VL, Colman DR (1995) Novel E-cadherin mediated adhesion in peripheral nerve: Schwann cell architecture is stabilized by autotypic adherens junctions. J Cell Biol 129:189-202.

Hahn A, Ainsworth PJ, Bolton CF, Bilbao JM, Vallat J-M (2001) Pathological findings in the X-linked form of Charcot-Marie-Tooth disease: a morphometric and ultrastructural analysis. Acta Neuropathol 101:129-139.

Hahn AF, Brown WF, Koopman WJ, Feasby TE (1990) X-linked dominant hereditary motor and sensory neuropathy. Brain 113:1511-1525.

Hahn AF, Bolton CF, Whiate CM, Brown WF, Tuuga SE, Tan CC, Ainsworth PJ (1999) Genotype/phenotype correlations in X-linked CharcotMarie-Tooth disease. Ann NY Acad Sci 883:366-382.

Harding AE, Thomas PK (1980) The clinical features of hereditary motor and sensory neuropathy types I and II. Brain 103:259-280.

Kirschner DA, Wrabetz L, Feltri ML (2004) The P0 gene. In: Myelin biology and disorders (Lazzarini RL, ed), pp 523-545. San Diego: Elsevier.

Kobsar I, Mäurer M, Ott T, Martini R (2002) Macrophage-related demyelination in peripheral nerves of mice deficient in the gap junction protein connexin 32. Neurosci Lett 320:17-20.

Kobsar I, Berghoff M, Samsam M, Wessig C, Mäurer M, Toyka KV, Martini R (2003) Preserved myelin integrity and reduced axonopathy in connexin32-deficient mice lacking the recombination activating gene-1. Brain 126:804-813.

Lee V, Wu HL, Schlaepfer WW (1982) Monoclonal antibodies recognized individual neurofilament triplet proteins. Proc Natl Acad Sci USA 79:6089-6092.

Lee VM-Y, Carden MJ, Schlaepfer WW, Trojanowski JQ (1987) Monoclonal antibodies distinguish several differentially phosphorylated states of the two largest rat neurofilament subunits (NF-H and NF-M) and demonstrate their existence in the normal nervous system of adult rats. J Neurosci 7:3474-3488.

Lemke G, Lamar E, Patterson J (1988) Isolation and analysis of the gene encoding for peripheral myelin protein zero. Neuron 1:73-83.

Leone DP, Genoud S, Atanasoski S, Grausenburger R, Berger P, Metzger D, Macklin WB, Chambon P, Suter U (2003) Tamoxifen-inducible gliaspecific Cre mice for somatic mutagenesis in oligodendrocytes and Schwann cells. Mol Cell Neurosci 22:430-440.

Li J, Hertzberg EL, Nagy JI (1997) Connexin32 in oligodendrocytes and association with myelinated fibers in mouse and rat brain. J Comp Neurol 379:571-591. 
Lupski JR, Garcia CA (2001) Charcot-Marie-Tooth peripheral neuropathies and related disorders. In: The metabolic and molecular basis of inherited disease, Ed 8 (Scriver CR, Beaudet AL, Sly WS, Valle D, Childs B, Kinzler KW, eds), pp 5759-5788. New York: McGraw-Hill.

Meier C, Dermietzel R, Davidson KGV, Yasumura T, Rash JE (2004) Connexin32-containing gap junctions in Schwann cells at the internodal zone of partial myelin compaction and in Schmidt-Lanterman incisures. J Neurosci 24:3186-3198.

Messing A, Behringer RR, Hammang JP, Palmiter RD, Brinster RL, Lemke G (1992) P0 promoter directs expression of reporter and toxin genes to Schwann cells of transgenic mice. Neuron 8:507-520.

Micevych PE, Popper P, Hatton GI (1996) Connexin 32 mRNA levels in the rat supraoptic nucleus: up-regulation prior to parturition and during lactation. Neuroendocrinology 63:39-45.

Nelles E, Butzler C, Jung D, Temme A, Gabriel H-D, Dahl U, Traub O, Stumpel F, Jungermann K, Zielasek J, Toyka KV, Dermietzel R, Willecke K (1996) Defective propagation of signals generated by sympathetic nerve stimulation in the liver of connexin32-deficient mice. Proc Natl Acad Sci USA 93:9565-9570.

Neuhaus IM, Dahl G, Werner R (1995) Use of alternative promoters for tissue-specific expression of the gene coding for connexin32. Gene 158:257-262.

Neuhaus IM, Bone L, Wang S, Ionasescu V, Werner R (1996) The human connexin 32 gene is transcribed from two tissue-specific promoters. Biosci Rep 16:239-248.

Nicholson G, Nash J (1993) Intermediate nerve conduction velocities define $\mathrm{X}$-linked Charcot-Marie-Tooth neuropathy families. Neurology 43:2558-2564.

Palmiter RD, Sandgren EP, Avarbock MR, Allen DD, Brinster RL (1991) Heterologous introns can enhance expression of transgenes in mice. Proc Natl Acad Sci USA 88:478-482.

Pedraza L, Owens GC, Green LAD, Salzer JL (1990) The myelin-associated glycoproteins: membrane disposition, evidence of a novel disulfide linkage between immunoglobulin-like domains, and posttranslational palmitylation. J Cell Biol 111:2651-2661.

Piddlesden S, Lassman H, Laffafian I, Morgan BP, Linington C (1991) Antibody-mediated demyelination in experimental allergic encephalomyelitis is independent of complement membrane attack complex formation. Clin Exp Immunol 83:245-250.

Pot C, Simonen M, Weinmann O, Schnell L, Christ F, Stoeckle S, Berger P, Rulicke T, Suter U, Schwab ME (2002) Nogo-A expressed in Schwann cells impairs axonal regeneration after peripheral nerve injury. J Cell Biol 159:29-35.

Rouger H, Le Guern E, Birouk N, Gouider R, Tardieu S, Plassart E, Gugenheim M, Vallat JM, Louboutin JP, Bouche P, Agid E, Brice A (1997) Charcot-Marie-Tooth disease with intermediate motor nerve conduction velocities: characterization of 14 Cx32 mutations in 35 families. Hum Mutat 10:443-450.

Rozear MP, Pericak-Vance MA, Fischbeck K, Stajich JM, Gaskell Jr PC, Krendel DA, Graham DG, Dawson DV, Roses AD (1987) Hereditary motor and sensory neuropathy, X-linked: a half century follow-up. Neurology $37: 1460-1465$.
Sander S, Nicholson GA, Ouvrier RA, McLeod JG, Pollard JD (1998) Charcot-Marie-Tooth disease: histopathological features of the peripheral myelin protein (PMP22) duplication (CMT1A) and connexin32 mutations (CMTX1). Muscle Nerve 21:217-225.

Scherer SS, Paul DL (2004) The connexin32 and connexin29 genes. In: Myelin biology and disorders (Lazzarini RL, ed), pp 599-608. San Diego: Elsevier.

Scherer SS, Deschênes SM, Xu Y-T, Grinspan JB, Fischbeck KH, Paul DL (1995) Connexin32 is a myelin-related protein in the PNS and CNS. J Neurosci 15:8281-8294.

Scherer SS, Xu Y-T, Nelles E, Fischbeck K, Willecke K, Bone LJ (1998) Connexin32-null mice develop a demyelinating peripheral neuropathy. Glia 24:8-20.

Scherer SS, Arroyo EJ, Peles E (2004) Functional organization of the nodes of Ranvier. In: Myelin biology and disorders (Lazzarini RL, ed), pp 89116. San Diego: Elsevier.

Senderek J, Hermanns B, Bergmann C, Boroojerdi B, Bajbouj M, Hungs M, Ramaekers VT, Quasthoff S, Karch D, Schröder JM (1999) X-linked dominant Charcot-Marie-Tooth neuropathy: clinical, electrophysiologi$\mathrm{cal}$, and morphological phenotype in four families with different connexin32 mutations. J Neurol Sci 167:90-101.

Söhl G, Gillen C, Bosse F, Gleichmann M, Muller HW, Willecke K (1996) A second alternative transcript of the gap junction gene connexin32 is expressed in murine Schwann cells and modulated in injured sciatic nerve. Eur J Cell Biol 69:267-275.

Solomon IC, Halat TJ, El-Maghrabi R, O’Neal MH (2001) Differential expression of connexin 26 and connexin 32 in the pre-Botzinger complex of neonatal and adult rat. J Comp Neurol 440:12-19.

Suter U, Scherer SS (2003) Disease mechanisms in inherited neuropathies. Nat Neurosci Rev 4:714-726.

Swett JE, Wikohm RP, Blanks RHI, Swett AL, Conley LC (1986) Motoneurons of the rat sciatic nerve. Exp Neurol 93:227-252.

Taketo M, Schroeder AC, Mobraaten LE, Gunning KB, Hanten G, Fox RR, Roderick TH, Stewart CL, Lilly F, Hansen CT, Overbeek PA (1991) $\mathrm{FVB} / \mathrm{N}$ : an inbred mouse strain preferable for transgenic analyses. Proc Natl Acad Sci USA 88:2065-2069.

Timmerman V, De Jonghe P, Spoelders P, Simokovic S, Lofgren A, Nelis E, Vance J, Martin J-J, Van Broeckhoven C (1996) Linkage and mutation analysis of Charcot-Marie-Tooth neuropathy type 2 families with chromosomes 1p35-p36 and Xq13. Neurology 46:1311-1318.

Trapp BD, Kidd GJ (2004) Structure of the myelinated axon. In: Myelin biology and disorders (Lazzarini RL, ed), pp 3-27. San Diego: Elsevier.

Wrabetz L, Feltri ML, Quattrini A, Imperiale D, Previtali S, D'Antonio M, Martini R, Yin XH, Trapp BD, Zhou L, Chiu SY, Messing A (2000) P0 glycoprotein overexpression causes congenital hypomyelination of peripheral nerves. J Cell Biol 148:1021-1033.

Wrabetz L, Feltri ML, Kleopa KA, Scherer SS (2004) Inherited neuropathies-clinical, genetic, and biological features. In: Myelin biology and disorders (Lazzarini RL, ed), pp 905-951. San Diego: Elsevier.

Yamamoto T, Hertzberg EL, Nagy JI (1991) Subsurface cisterns in $\alpha$-motoneurons of the rat and cat: immunohistochemical detection with antibodies against connexin32. Synapse 8:119-136. 